\title{
Penggunaan Infografis pada Akun Instagramtirtoid sebagai Strategi Cross-media
}

\author{
Retno Nurul Aisyah, Efi Fadilah, dan Nuryah Asri Sjafirah \\ Fakultas Ilmu Komunikasi, Universitas Padjadjaran \\ E-mail: aisyahretno69@gmail.com
}

\begin{abstract}
Tirto.id uses infographics on its Instagram account "tirtoid" as an attempt to enlarge the online media market. The strategy that is called cross-media refers to diversification and integration decisions of different media platforms. This study is an inquiry of how the cross-media strategy occurs on tirtoid Instagram account using Infographic as the main feature through the case study method. The data collection techniques using interviews, observation, and literature reviews. The results showed that four reasons motivated the use of infographics on tirtoid Instagram account; segmentation of audiences, the character of the platform, the ease of production, and the character of the company. These reasons were conformed with the concept of cross-media strategy that emphasizing the appropriateness of media choices and the content presented. In the producing process of infographics, there are six stages implemented by Tirto.id. Tirtoid gives unique characteristics to its infographics based on the principles and ethics of journalism. Tirto.id uses the principles of reuse, repackaging, and recreating in the distribution and development of infographic content on Instagram, which builds agenda setting practices. This cross-media strategy of using Instagram has an impact on the increasing need for production team Human Resources (HR), brand strengthening, and opening of new marketing opportunities.
\end{abstract}

Keywords: cross-media; infographics; instagram; social media; strategy.

\begin{abstract}
Abstrak
Strategi cross-media (penyilangan media) adalah strategi diversifikasi dan pengintegrasian yang dilakukan oleh media massa di platform media lainnya termasuk media sosial. Tirto.id merupakan salah satu media massa yang menerapkan strategi ini dengan menggunakan infografis di akun Instagram-nya. Penelitian ini bertujuan untuk mengetahui bagaimana penggunaan infografis pada akun Instagramtirtoid sebagai strategi cross-media melalui metode studi kasus.Hasil penelitian menunjukkan kebijakan Tirto.id menggunakan infografis di Instagram dilatarbelakangi empat pertimbangan; segmentasi khalayak, sifat dan karakter platform, kemudahan produksi, dan karakter perusahaan. Keempat pertimbangan ini sesuai dengan konsep dasar strategi cross-media yang menekankan pada kesesuaian pilihan media dan konten yang disajikan. Dalam proses produksi konten infografis, ada enam tahapan yang dilaksanakan Tirto.id. Tirto. id memberikan karakter khas pada infografisnya yang dilandaskan pada prinsip dan etika jurnalistik. Tirto.id menggunakan prinsip reuse, repackaging, dan recreate dalam pendistribusian dan pengembangan konten infografis di Instagram yang pada dasarnya membangun praktik agenda setting. Strategi cross-media menggunakan Instagram ini berdampak pada meningkatnya kebutuhan sumber Daya Manusia (SDM) tim produksi, penguatan brand, dan terbukanya peluang baru pemasaran.
\end{abstract}

Kata kunci: cross-media; infografis; instagram; media sosial; strategi.

\section{Pendahuluan}

Sinergitas menjadi tren dalam pengelolaan media massa dewasa ini agar terhubung dengan khalayaknya. Bentuk sinergitas yang umum berlaku terjalin antara portal berita online

Korespondensi: Retno Nurul Aisyah, Fakultas Ilmu Komunikasi Universitas Padjadjaran, Jl. Raya Jalan Raya Sumedang-Bandung Km.21, Kampus Fikom, Universitas Padjadjaran Jatinangor. 45363, E-mail: aisyahretno69@gmail.com

Menyerahkan: Juli 2019, Diterima: Januari 2020, Terbit: Januari 2020

ISSN: 2549-0559 (cetak), ISSN: 2549-1946 (online), Website: http://jurnal.unpad.ac.id/kajian-jurnalisme 
dengan beragam jenis media sosial atau antara media massa konvensional dengan media online dan media sosial. Langkah sinergitas dapat dilihat sebagai usaha penyesuaian diri media massa dengan kemajuan teknologi informasi dan perubahan perilaku khalayak. Sejalan berkembangnya penetrasi media sosial, strategi sinergitas media massa tidak dapat mengesampingkan media sosial. Hasil survei Polling Indonesia dan APJII tahun 2016 mencatat jumlah pengguna internet di Indonesia tahun 2016 sebanyak 132,7 juta dari total jumlah penduduk sebesar 256,2 juta atau sekitar 51,5\% penduduk Indonesia merupakan pengguna internet (APJII, 2016). Media sosial berada di posisi pertama sebagai konten internet yang paling sering diakses yakni 97,4\% atau 129,2 juta penduduk mengaksesnya (We Are Social, 2016). Besarnya jumlah pengguna media sosial di Indonesia menjadi landasan bagi media massa untuk memanfaatkan media sosial sebagai saluran penyebaran informasi (Insani, Hidayat, \& Zulfan, 2019).

Situs berita Tirto.id menggunakan peluang ini dengan mengelola beragam aku media sosial, salah satunya akun Instagram bernama "tirtoid". Pada 20 Juni 2016, Instagramtirtoid mengunggah konten untuk pertama kalinya berupa foto jurnalistik keterangan foto dalam tiga kalimat panjang. Pada 3 Agustus 2016, Instagramtirtoid menambah konten berformat video berita singkat. Konten foto dan video terus digunakan Tirto.id selama 8 bulan. Berdasarkan survei Polling Indonesia dan APJII tahun 2016, Instagram merupakan media sosial kedua yang paling banyak digunakan di Indonesia (15\%) setelah Facebook (54\%) (APJII, 2016). Akan tetapi, akun media sosial milik Tirto.id memperlihatkan hal sebaliknya dimana akun Instagram tirtoid lebih aktif dan banyak diakses dibandingkan akun Facebook-nya. Pada Facebook Tirto. id klik suka untuk unggahan hanya mencapai angka 200 klik suka dan komentar rata-rata 4-10 komentar per unggahan. Sedangkan Instagram tirtoid bisa mendapatkan rata-rata 2.000 hingga 9.000 klik suka dan komentar mencapai 20-300 komentar per unggahan.

Pada bulan kesembilan tepatnya 28 Februari 2017, untuk pertama kalinya akun Instagram tirtoid menampilkan konteks berbentuk infografis. Infografis ini memuat informasi mengenai "Profil Pengetik Naskah Proklamasi Sayuti Melik" yang disajikan lewat model time record. Unggahan ini disukai sebanyak 158 pengguna, angka tertinggi dibandingkan unggahan sebelumnya dalam bentuk foto dan video. Pada konten tersebut juga dicantumkan sumber data berasal dari "Artikel Tirto.id", sesuatu yang tidak dilakukan dalam 8 bulan sebelumnya. Perubahan demi perubahan ini berdampak positif pada meningkatnya engagement atau aktivitas followers di Instagramtirtoid

Infografis merupakan singkatan dari informasi grafik adalah sejenis gambar yang menggabungkan data dengan desain yang membantu seseorang ataupun organisasi mengomunikasikan pesan mereka kepada khalayak dengan lebih singkat. Menurut Smiciklas (2012) "an infographic is defined as a visualization of data or ideas that tries to convey complex information to an audience in a manner that can be quickly consumed and easily understood".

Penelitian Arigia, Damayanti, \& Sani (2016) menunjukkan bahwa tampilan infografis membantu menarik perhatian dan pemahaman khalayak akan informasi khusus dan kompleks. Infografis dinilai mampu memaparkan secara artistik dan tidak terpaku hanya pada penggambaran hasil data dan memberikan visualisasi menyegarkan dari data yang bersifat sangat numerik serta visualisasi peristiwa atau fakta. Terutama bagi surat kabar, infografis berperan menghindari tata letak koran atau majalah yang menjenuhkan (Wicandra, 2006).

Penyajian pesan atau informasi dalam bentuk infografis mulai semakin luas digunakan oleh media massa termasuk pada akun media sosialnya. Media sosial mengandalkan dan membentuk visual thinking, dimana foto, gambar, warna, bentuk, dan elemen visual lainnya lebih mendominasi. Dampaknya, khalayak kini menginginkan segala sesuatu yang menstimulasi secara visual (Wood, 2009). Di sisi lain, media sosial juga memiliki karakter ringkas dan cepat. 
Karakter visual, ringkas, dan cepat dari media sosial ini menuntut media massa harus mampu menyusun strategi yang tepat dalam menyajikan konten di media sosial.

Peneliti melihat adanya suatu strategi cross-media yang diterapkan oleh Tirto.id dalam konten infografis di akun Instagram-nya. Strategi cross-media (penyilangan media) adalah strategi diversifikasi dan pengintegrasian yang dilakukan oleh media massa pada platform media lain termasuk media sosial. Sjurts (dalam Feldmann, 2005) mendefinisikan strategi cross-media sebagai keputusan diversifikasi perusahaan media yang menargetkan pasar media lainnya. Diversifikasi pada definisi ini merujuk pada berbagai jenis media tradisional seperti koran, majalah, penyiaran, dan juga termasuk media baru yakni internet dan media mobile. Strategi cross-media berarti pendistribusian konten di lebih dari satu media atau pada berbagai jenis perangkat penerima yang berbeda (Tassel \& Poe-Howfield, 2010). Strategi cross-media bergantung pada kesesuaian pilihan media dan konten yang disajikan. Strategi ini lebih kuat pengaruhnya jika diintegrasikan pada proses produksi konten media.

Berdasarkan pertimbangan tersebut, penelitian ini merumuskan fokus masalah pada penggunaan infografis pada akun Instagramtirtoid sebagai strategi cross-media. Rumusan ini diturunkan menjadi beberapa butir pertanyaan penelitian yang menggali latar belakang kebijakan pemilihan infografis sebagai bentuk utama konten pada akun Instagramtirtoid, proses produksi konten infografis pada akun Instagramtirtoiddan penerapan penerapan strategi crossmedia dalam distribusi dan pengembangan konten infografis di akun Instagramtirtoid.

\section{METODE}

Penelitian ini menggunakan metode penelitian kualitatif dengan pendekatan studi kasus jenis studi kasus intrinsik. Pada studi kasus intrinsik, fokus penelitian tertuju pada kasus dengan nilai keunikan atau tidak biasa (Creswell, 2013). Infografis pada akun Instagramtirto.id tergolong unik dibanding akun Instagram media massa lainnya terkait beragam aspek, seperti konten, tampilan, dan sumber.

Data penelitian diperoleh melalui wawancara, observasi, dan studi pustaka. Informan penelitian terdiri dari para pengelola media sosial portal berita tirto.id dan pengamat media sosial Rulli Nasrullah. Pengamatan atau observasi bertujuan melihat perkembangan aktivitas pada akun Instagramtirtoid, meliputi jumlah klik suka pada setiap unggahan, jumlah komentar, keselarasan visual, caption, dan tanggapan positif serta negatif pada kolom komentar.Kajian pustaka dalam penelitian bertujuan menelaah landasan teoritis dan konseptual masalah penelitian melalui buku-buku referensi dan hasil penelitian sebelumnya. Di dalam studi kasus, kajian pustaka berfungsi untuk mendukung dan menambah bukti dari sumber-sumber lain (Yin, 2015). Di dalam penelitian ini, penelusuran pustaka mengacu pada penelusuran sumbersumber konvensional maupun sumber digital dari Internet.

Data penelitian dianalisis menggunakan 6tahapanalisis datakualitatifyang bersifatinduktif (Bungin, 2008) yakni (1) melakukan pengamatan, identifikasi, revisi, dan (2) pengecekan ulang data yang ada, (3) melakukan kategorisasi terhadap informasi yang diperoleh, (4)menjelaskan kategorisasi, (5)menjelaskan hubungan antar kategori, dan (6) menarik kesimpulan.

Peneliti menggunakan teknik triangulasi dalam memeriksa keabsahan data. Triangulasi merupakan pemeriksaan keabsahan data dengan memanfaatkan sesuatu yang lain di luar dari data sebagai pembanding dan cross-check kebenaran dan ketepatan data (Moleong, 2017). Triangulasi menggunakan multi persepsi untuk mengklarifikasi makna, memverifikasi ulang hasil amatan atau interpretasi hasil. Dalam penelitian ini digunakan triangulasi sumber data dan triangulasi metode (Bungin, 2008)dengan cara berikut:

- Membandingkan data hasil wawancara dengan hasil observasi. 
- Membandingkan data hasil wawancara dan observasi dengan studi kepustakaan dan penelusuran online.

- Membandingkan hasil wawancara satu informan dengan hasil wawancara informan lain yang berada dalam satu institusi (cross check data pada setiap anggota tim divisi media sosial Tirto.id)

- Membandingkan hasil wawancara satu informan dengan hasil wawancara informan lain yang berada di luar institusi (cross check data kepada informan dari pengamat media, Rulli Nasrullah)

\section{HASIL DAN PEMBAHASAN}

Sebelum era media baru berkembang pesat, khalayak memenuhi kebutuhan akan informasi lewat berbagai jenis media massa arus utama, seperti televisi, koran, radio, dan internet. Saat membutuhkan informasi khalayak akan langsung membuka koran, menonton televisi dan memilih siaran berita, mendengarkan radio, atau melakukan pencarian di situs media massa daring.

Perilaku khalayak ini mengalami pergeseran sejak digitalisasi dan internet berkembang sangat cepat dalam bentuk mobile device atau lebih dikenal telepon pintar. Kini khalayak tidak hanya menjadikan media sosial sebagai jejaring komunikasi pribadi tapi juga sebagai wadah pencarian informasi. Khalayak yang lebih sering terhubung dengan telepon pintar dan akun media sosial membuat pencarian dan pembaharuan informasi dilakukan oleh khalayak melalui media sosial .

Perubahan perilaku khalayak dalam konsumsi informasi berdampak pada media massa. Media massa yang memiliki peran dalam menyampaikan informasi pada khalayak, melihat adanya peluang penyebaran informasi melalui media sosial. Tirto.id adalah salah satu media massa yang melihat peluang tersebut.

Tirto.id merupakan media daring dengan nama portal http://Tirto.id yang berdiri pada April 2016. Nama Tirto.id berarti tirta atau air. Filosofi air mengalir, mengisi ceruk, dan sekaligus jernih, menunjukkan kedalaman. Nama "Tirto" juga ditujukan kepada Tirto Adhi Soerjo (1880-1918), Bapak Pers Indonesia sekaligus Pahlawan Nasional. Tirto.id merupakan media daring dengan konsep jurnalisme presisi. Tirto.id memanfaatkan data berwujud foto, kutipan, rekaman peristiwa, serta data statistik yang ditampilkan secara langsung ataupun lewat infografis dan video infografis.

Dengan kesaradaran dinamika perubahan perilaku khalaya, Tirto.id berusaha menyesuaikan diri melalui kebijakan diversifikasi dan integrasi konten di media sosial. Keputusan diversifikasi perusahaan media yang menargetkan pasar media lainnya ini dikenal dengan istilah strategi cross-media (Sjurts dalam Feldmann, 2005). Dengan kata lain, Tirto. id mengambil kebijakan penggunaan strategi cross-media di media sosial untuk menghadapi perubahan perilaku konsumsi informasi khalayak.

Strategi cross-media muncul sebagai akibat berkembangnya teknologi informasi yang melahirkan berbagai jenis media baru. Bailey Socha dan Barbara Eber-Schmid dari New Media Institute (2014) menjelaskan media baru sebagai kata yang digunakan secara umum di abad 21 untuk mendefinisikan segala hal yang berkaitan dengan internet dan saling interaksi antara teknologi, gambar, dan suara. Media sosial adalah salah satu jenis dari media baru atau new media tersebut.

Pada tanggal 20 Juni 2016, Tirto.id mengunggah konten pertama kalinya di akun Instagram-nya "tirtoid". Bentuk konten yang digunakan dalam unggahan ini adalah foto jurnalistik. Konten foto jurnalistik terus digunakan, hingga pada 3 Agustus 2016, ditambahkan 
bentuk konten baru yakni video berita. Hingga bulan Januari 2017, konten yang digunakan berbentuk foto dan video jurnalistik.

Pada 28 Februari 2017, Tirto.id melakukan inovasi bentuk konten di akun Instagramnya menjadi infografis. Bentuk infografis terus menghiasi linimasa atau feed Instagram Tirto.id sejak unggahan per 28 Februari ini. Konten infografis menjadi ciri khas akun Instagramtirtoid yang dipertahankan hingga kini.

Gambar 1. Perubahan Pola Konten di Akun Instagram tirtoid

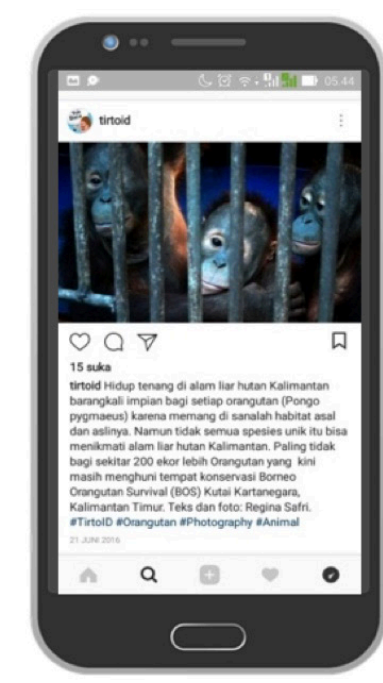

Foto Jurnalistik

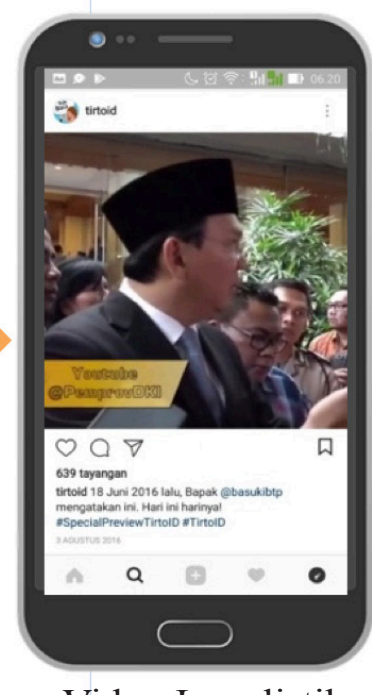

Video Jurnalistik

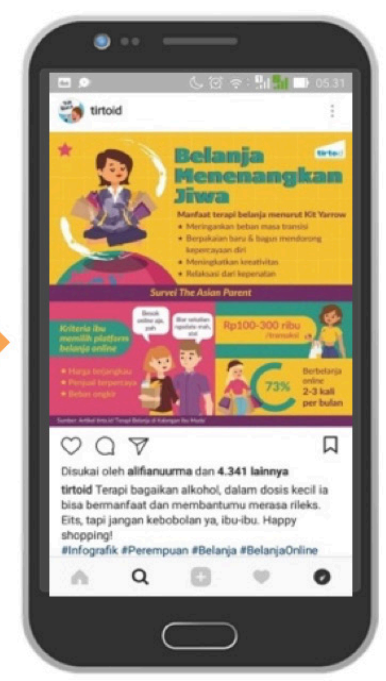

Infografis

Sumber: Peneliti 2018

Perubahan kebijakan bentuk konten dari foto dan video jurnalistik menjadi infografis ini, didasarkan pada empat pertimbangan. Pertama, segmentasi khalayak. Akun InstagramTirto. id terdiri dari khalayak dengan usia 18-35 tahun. Khalayak usia ini dapat dikatakan sebagai pembaca muda atau digital natives. Digital natives adalah istilah yang digunakan untuk mereka yang lahir dalam era digital.

Pembaca muda cenderung lebih mudah dalam memahami konten gambar ketimbang teks. Pembaca muda juga cenderung menginginkan informasi bersifat segera, sehingga kurang mentolerir hal yang lambat. Karakter khalayak ini sesuai dengan sifat infografis yang mampu mengemas informasi dengan cepat, ringkas, dan menarik.

Kedua, sifat dan karakter platform. Instagram merupakan platform media sosial yang memungkinkan penggunanya untuk berbagi foto, gambar, dan video kepada pengguna lain (Landsverk, 2014). Ini artinya, Instagram mendukung segala bentuk konten yang bersifat visual. Jika media sosial lain mengandalkan informasi teks atau tulisan, di Instagram konten berbicara dalam bentuk visual yang ringkas. Infografis dinilai Tirto.id sebagai bentuk konten yang tepat untuk menyeimbangi sifat dan karakter Instagram ini.

Ketiga, kemudahan dalam produksi. Sebelum ditetapkannya infografis sebagai bentuk konten utama di Instagram-nya Tirto.id menggunakan bentuk konten foto dan video jurnalistik. Tirto.id menyadari foto dan video tidak dapat diproduksi setiap hari. Sementara itu, untuk terus menjangkau khalayak di Instagram, sebuah akun Instagram harus mampu membagikan unggahan baru setiap harinya. Tirto.id melihat infografis menjadi pilihan tepat karena dapat diproduksi setiap hari. Ini karena infografis berbeda dengan foto dan video jurnalistik yang tidak terikat dengan peristiwa atau kejadian untuk dapat diproduksi. Pertimbangan ini menunjukkan Tirto.id yang merencanakan produksi konten jangka panjang. Sehingga Tirto.id 
mencari bentuk konten yang tidak hanya dapat diproduksi dalam beberapa kali saja tapi konten yang berkelanjutan.

Keempat, karakter perusahaan. Tirto.id berdiri sebagai media massa atas dasar jurnalisme berbasis data. Dalam setiap karya jurnalistik yang disajikan, Tirto.id selalu menggunakan data. Karakter inilah yang menjadi salah satu pertimbangan dipilihnya infografis sebagai bentuk konten di akun Instagramtirtoid. Infografis memungkinkan Tirto.id menyampaikan data yang padat dengan lebih ringkas dan menarik. Sehingga khalayak juga lebih mudah dalam memahami informasi yang didapatkan.

Konten merupakan hal utama bagi industri media dalam menerapkan strategi crossmedia. Istilah "konten adalah raja" menjadi umum di bidang media dan di era digital sejumlah perusahaan media menerapkan prinsip "satu konten untuk diterbitkan di berbagai saluran". Cross-media dari media daring menuju media sosial berjalan berlandaskan prinsip ini. Sebagai strategi, cross-media menjadi pertimbangan banyak media karena konten dapat terus diformat, dikemas, dan disalurkan melalui berbagai platform media tambahan.

Untuk mencapai strategi itu, Tirto.id melakukan langkah penggunaan ulang (reuse), pengemasan ulang (repackaging), dan pembentukan ulang (recreation), dari konten artikel yang ada di website. Artikel yang telah dibagikan di website digunakan ulang (reuse) sebagai sumber data pembuatan infografis. Artikel yang semula berbentuk tulisan, dikemas ulang (repackaging) dalam bentuk infografis. Infografis yang diproduksi dikreasikan atau dibentuk ulang (recreation) dengan karakter khas yang berbeda.

Ada enam proses produksi konten infografis pada akun Instagram tirtoid, yaitu:

1. Rapat Perencanaan

Rapat perencanaan dilaksanakan 1x dalam seminggu dan diikuti oleh seluruh anggota tim divisi media sosial. Dalam rapat ini dibahas berbagai perencanaan kegiatan yang akan dilakukan oleh seluruh tim dalam satu minggu ke depan. Dalam rapat divisi dibahas pula berbagai isu dan agenda yang telah, sedang, dan akan terjadi.

2. Pembuatan Brief

Pembuatan brief adalah proses pengkurasian artikel oleh admin ke dalam poin-poin intisari hingga menjadi sebuah brief. Dalam satu hari, admin Instagram harus membuat minimal 3 brief yang bisa disarikan dari tiga artikel berbeda ataupun dari satu artikel saja.

Tabel 1. Format Brief Infografis

\begin{tabular}{|l|l|l|l|l|}
\hline \multicolumn{1}{|c|}{ PIC } & Image Size & \multicolumn{1}{|c|}{$\begin{array}{l}\text { Image } \\
\text { Status }\end{array}$} & \multicolumn{1}{|c|}{ Text on Image } & \multicolumn{1}{c|}{ URL } \\
\hline $\begin{array}{l}\text { Fifa } \\
\text { Erenn }\end{array}$ & $1200 \times 1200$ & & $\begin{array}{l}\text { KAMI DARI...GENG MOTOR! (ada leda- } \\
\text { kan knalpot) } \\
\text { (b) 3 golongan geng(b) } \\
\text { (b) Kekerasan(b) } \\
\text { Beroperasi untuk menegaskan daerah teritori } \\
\text { (b) Kriminal(b) } \\
\text { Punya motif ekonomi, contoh:preman } \\
\text { (b) Retrearist(b/i) }\end{array}$ & $\begin{array}{l}\text { https:/tirto.id/ } \\
\text { geng-motor-indo- } \\
\text { nesia-dan-ameri- } \\
\text { ka-dari-beda-mo- } \\
\text { tor-hingga-krimi- } \\
\text { nal-cFTt }\end{array}$ \\
& & & \\
\hline
\end{tabular}

Sumber: Divisi Media Sosial Tirto.id, 2018

Adapun ketentuan artikel yang disarikan, dipilih atas dua pertimbangan. Pertama, artikel memiliki informasi yang menarik, populer, dan penting. Kedua, artikel juga memiliki premis data yang menarik apabila dikemas dalam bentuk infografis. Kriteria menarik, disesuaikan dengan demografi atau khalayak Instagram Tirto.id. Isu yang menarik bagi khalayak Instagram ini dapat dilihat dari laporan mingguan yang diolah oleh marketer. Isu konten yang 
mendapatkan engagement yang tinggi dari khalayak, akan menjadi pertimbangan nilai menarik ini. Sedangkan kriteria penting berdasarkan pada data yang dirasa perlu bagi khalayak untuk mengetahuinya.

\section{Visualisasi Brief}

Setelah brief artikel selesai, selanjutnya diteruskan oleh desainer untuk proses pemvisualisasian teks brief menjadi infografis. Erenn Pratama sebagai desainer infografis menjelaskan adanya istilah key visual atau gambar dan simbol pokok pada infografis yang dibuat.

Istilah key visual merupakan istilah yang digunakan dalam desain periklanan, terutama dalam pembuatan logo. Menurut situs fameable.com key visual berarti motif gambar yang digunakan untuk mengekspresikan komunikasi dengan jelas dan efektif serta menghadirkan emosi yang diharapkan terjadi pada target audiens. Tirto.id sendiri, mengembangkan dan menggunakan istilah ini untuk menyebut elemen gambar yang menjadi titik fokus dari konten infografis.

Tirto.id menggunakan dua jenis key visual dalam memvisualisasikan teks brief. Pertama, single visual key, merupakan infografis yang terdiri dari satu gambar utama. Gambar diletakkan di tengah dan banyak teks mengelilingi gambar tersebut. Kedua, multi visual key, merupakan infografis yang terdiri dari perpaduan beberapa gambar dan beberapa teks.

Gambar 2. Penggunaan Key Visual di Infografis

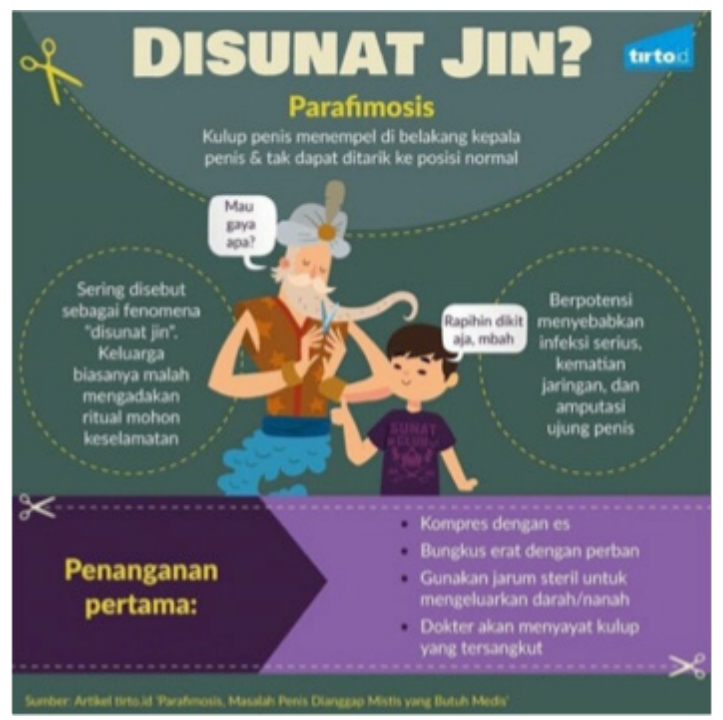

kiri: Single Key Visual

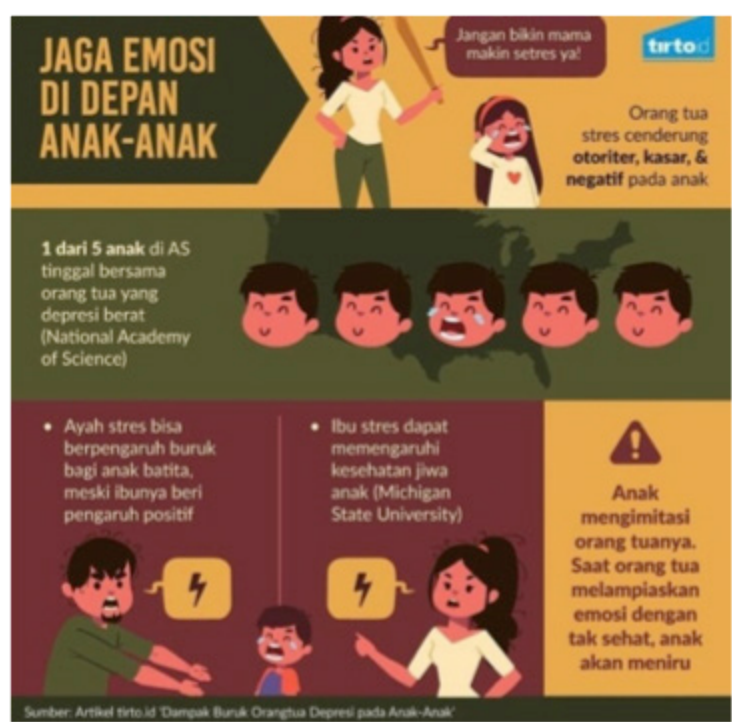

kanan: Multi Key Visual

Sumber: Akun instagram tirtoid, 2018

Tirto.id memiliki beberapa karakter khas dalam desain infografis di Instagram-nya. Pertama, penggunaan maskot "Pak Tirto". Maskot "Pak Tirto" digambarkan sebagai sosok laki-laki yang selalu menggunakan blankon coklat, tuksedo, celana panjang, serta pantofel bewarna hitam.

Kedua, penggunaan jokes atau guyonan sebagai salah satu elemen infografis. Guyonan ini dikemas dalam bentuk balon percakapan. Guyonan ini bertujuan agar infografis lebih komunikatif dan hidup. Komunikatif berarti infografis memiliki sisi human interest. Infografis tidak sekedar memaparkan teks dan gambar tetapi juga berinteraksi dengan para pengguna melalui guyonan ini. 
Volume 03 Nomor 02 Tahun 2020

DOI: $10.24198 / \mathrm{jkj} . \mathrm{v} 3 \mathrm{i} 2.22276$

Gambar 4. Penggunaan Guyonan agar Infografis lebih Komunikatif

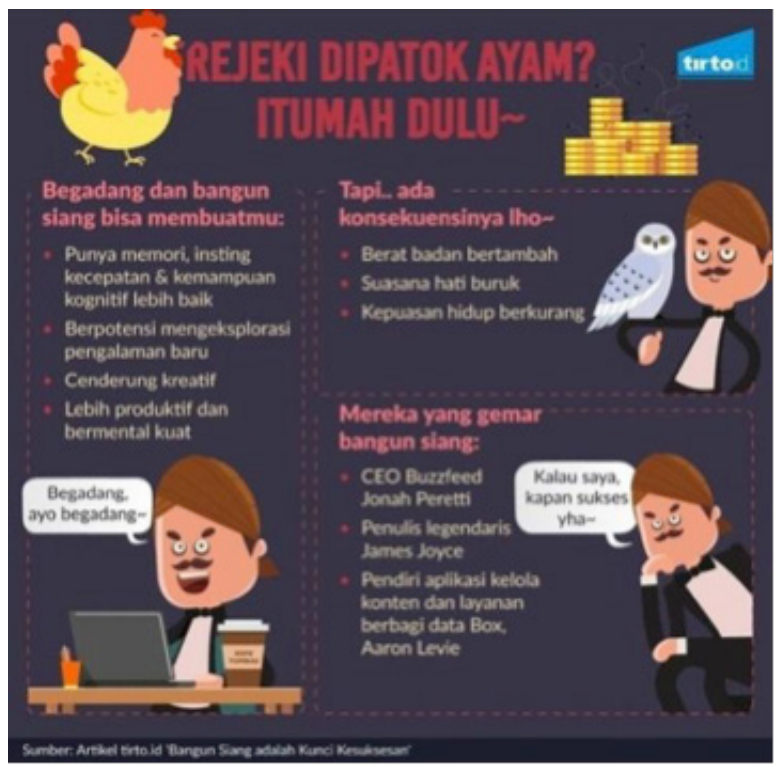

Sumber: Akun Instagramtirtoid, 2018

Ketiga, penggunaan gambar atau ilustrasi surealis. Kamus Besar Bahasa Indonesia (KBBI mengartikan surealisme sebagai aliran dalam seni sastra yang mementingkan aspek bawah sadar manusia dan irasional dalam citraan (di atas atau di luar realitas atau kenyataan). Surealis juga bisa disebut dengan penganalogian. Gambar dalam bentuk analogi ditujukan untuk menarik perhatian (visualattention) pengguna. Sehingga, saat melihat infografis Tirto. id muncul pada feedInstagram, pengguna tertarik dan berhenti untuk membaca informasi yang ada pada infografis .

Gambar 5. Gambar Surealis untuk Menarik Perhatian Khalayak

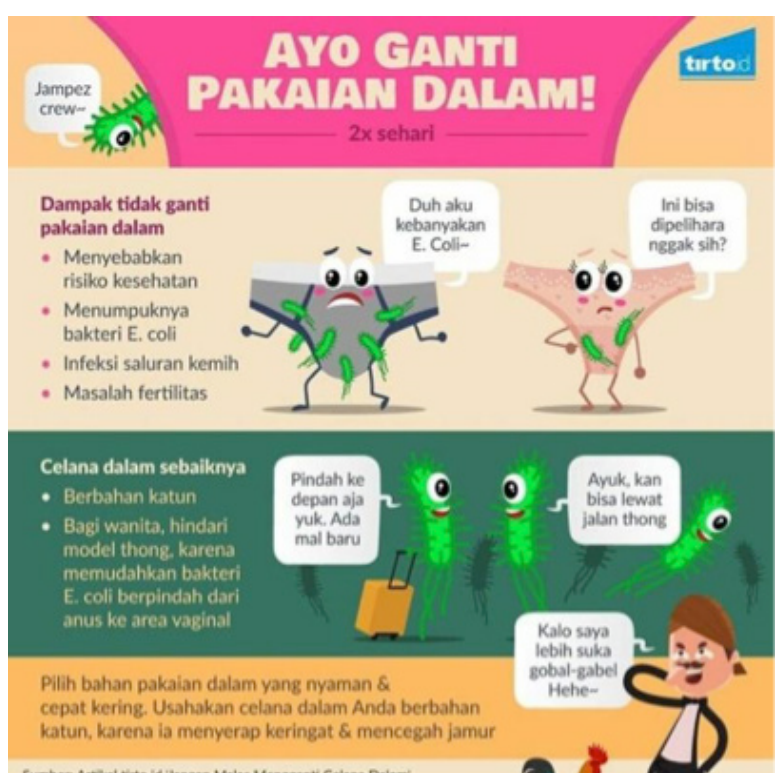

Sumber: Akun Instagram tirtoid, 2018

\section{Editor Approving}

Tahap berikutnya adalah editor approving atau persetujuan desain oleh editor untuk diunggah. Dalam tahap ini, editor dan manajer media sosial akan melakukan pemeriksaan infografis yang sudah selesai diproduksi. Pemeriksaan ini terdiri dari; kesalahan data dan 
DOI: $10.24198 /$ jkj.v3i2.22276

penulisan, penggunaan warna dan gambar, serta keselarasan desain.

\section{Penjadwalan dan Pengunggahan}

Desain yang telah melalui proses editor approving, selanjutnya diunggah di aplikasi dropbox. Admin harus mengecek setiap desain yang masuk dan melakukan waktu penjadwalan unggahan setiap desain. Hal ini dilakukan agar tidak terjadinya tumpang tindih serta mencegah pengulangan unggahan.

\section{Pelaporan dan Evaluasi}

Pelaporan merupakan tanggung jawab marketer media sosial dengan cara menghimpun seluruh data statistik tanggapan khalayak terhadap setiap setiap konten yang diunggah. Marketer juga mencatat grafik perkembangan aktivitas pengguna media sosial di akun Instagramtirtoid. Laporan ini menjadi salah satu instrumen yang digunakan dalam evaluasi.

Evaluasi dilakukan setiap satu kali dalam seminggu dalam bentuk rapat evaluasi divisi. Pada rapat evaluasi, dilakukan penyampaian laporan aktivitas Instagram selama satu minggu ke belakang. Dari laporan tersebut, dilakukan evaluasi terhadap konten dan evaluasi kinerja tim. Apabila evaluasi menunjukkan rencana berjalan sesuai dengan harapan, maka dirumuskan peningkatan serta pertahanan yang akan dilakukan. Jika evaluasi menunjukkan hasil yang negatif, maka perencanaan baru akan dibentuk atau perencanaan sebelumnya dikoreksi dan diperbaharui.

Tirto.id melakukan pendistribusian konten ini pada tiga akun media sosialnya, yakni, Facebook, Twitter, dan Instagram. Tirto.id menggunakan Instagram untuk mendistribusikan konten artikel yang berasal dari website. Artikel dalam bentuk tulisan didistribusikan di Instagram menjadi bentuk infografis. Pada facebook dan twitter distribusi dilakukan dalam bentuk tautan yang mengarahkan khalayak menuju artikel di laman Tirto.id.

Jika di Instagram seluruh konten berasal dari website, sedikit berbeda pada facebook dan twitter, dimana konten yang didistribusikan juga bersumber dari infografis Instagram. Ini menunjukkan bahwa konten InstagramTirto.id tidak hanya mendistribusikan informasi dari website tapi juga didistribusikan kembali (redistribusi) di media sosial lainnya.

Tindakan distribusi yang dilakukan oleh Tirto.id pada akun media sosialnya, menunjukkan adanya usaha Tirto.id dalam menerapkan strategi cross-media sebagai upaya menyesuaikan diri dengan perubahan yang terjadi pada khalayak. Pendistribusian konten di media sosial memberikan peluang yang lebih besar bagi Tirto.id untuk memperluas jangkauan khalayak.

Era media baru tidak hanya mengubah perilaku khalayak dalam menjadikan media sosial sebagai sumber informasi, tapi juga mengubah perilaku khalayak dalam menentukan pilihan informasi. Jika era media cetak dan elektronik membentuk khalayak yang pasif dan hanya menjadi penerima seluruh informasi dari media massa, era media baru memberikan kesempatan bagi khalayak untuk memilih informasi sesuai dengan apa yang diinginkan dan dibutuhkan. Dengan kata lain, khalayak menjadi lebih selektif dibandingkan era sebelumnya.

Untuk menjelaskan perubahan khalayak menjadi selektif ini, penulis mengutip penjelasan Rulli Nasrullah dalam bukunya Media Sosial: Perspektif Komunikasi, Budaya, dan Sosioteknologi:

"Pada masa awal-awal, sebagaimana teori komunikasi khalayak dianggap sebagai individu atau kelompok yang pasif dan hanya menerima terpaan media. Kemudian muncul era budaya massa dimana khalayak memiliki peran aktif dalam mengembangkan budaya yang berasal dari media. Era selanjutnya adalah era efek terbatas yang menunjukkan bahwa sebenarnya apa yang diproduksi media tidak serta merta memiliki efek bagi khalayak dan bersamaan dengan 
itu khalayak "berkuasa" menentukan pilihan produk informasi atau berita yang ingin mereka konsumsi. Artinya, posisi khalayak pada akhirnya juga memiliki kekuatan dalam memilih media, bahkan dalam penciptaan makna terhadap pesan" (Nasrullah, 2016).

Saat menggunakan media sosial, khalayak lebih bebas dan aktif dalam memilih akun mana yang akan dijadikan referensi dan konten informasi apa yang ingin dikonsumsi. Pada tahap inilah, poin kedua dari strategi cross-media diterapkan, yakni pengembangan konten. Media massa yang menerapkan strategi cross-media di media sosial memerlukan pengembangan konten untuk dapat membuat akun media sosialnya menjadi referensi dan pilihan oleh khalayak.

Untuk menghadapi perubahan khalayak yang selektif ini, Tirto.id mengembangan konten dengan melakukan tindakan penggunaan ulang (reuse), pengemasan ulang (repackaging), dan pembentukan ulang (recreation), dari konten artikel yang ada di website. Artikel yang telah diunggah di website digunakan ulang (reuse) sebagai sumber data pembuatan infografis. Artikel yang semula berbentuk tulisan, dikemas ulang (repackaging) dalam bentuk infografis. Infografis yang diproduksi dikreasikan atau dibentuk ulang (recreation) dengan karakter khas yang berbeda yakni penggunaan guyonan, maskot "Pak Tirto", dan gambar surealis.

Di samping infografis, Tirto.id juga mengembangkan konten dalam bentuk videografis di Instagram-nya. Tirto.id memiliki tiga jenis konten videografis yakni; Video Mozaik, Tirto Kilat, dan Tirto Ringkas. Video grafis merupakan gabungan beberapa elemen grafis ditambah dengan gambar atau foto, suara, dan adanya storyboard atau alur.

Kedua bentuk ini, infografis dan video-grafis, dikembangkan dari satu sumber yaitu konten artikel yang ada di website Tirto.id. Pengembangan konten dalam bentuk infografis dan videografis di Tirto.id adalah salah satu strategi yang dibentuk Tirto.id untuk menarik minat khalayak pada konten yang dimiliki. Peneliti menilai tindakan Tirto.id ini sebagai suatu cara untuk menghadapi keselektifan khalayak pada media dan konten media di era media baru.

Infografis dan videografis memiliki poin visual sebagai suatu kekuatan. Di media sosial, visual menjadi nilai yang dipertimbangkan oleh khalayak. ini disebabkan terpaan visual terus menerus yang diterima khalayak di era media baru. Dampaknya khalayak menginginkan segala sesuatu yang menstimulasi secara visual (Wood, 2009). Maka, pengembangan konten dalam bentuk infografis dan video grafis yang digunakan Tirto.id menjadi pilihan yang sesuai, terutama untuk khalayak Instagram yang menjadikan visual sebagai salah satu faktor pertimbangan dalam pemilihan konten informasi yang akan dijadikan referensi.

Sebagai media yang menjalankan kerja jurnalisme, Tirto.id tidak lepas dari prinsip dan etika jurnalisme dalam pelaksanaan tindakan produksi konten cross-media di media sosialnya. Prinsip jurnalisme dikenal dengan nama lain "elemen jurnalisme". Bill Kovach \& Tom Rosenstiel (2003) memperkenalkan 9 elemen jurnalisme yang kemudian menjadi prinsip dari setiap kegiatan jurnalisme. Di samping prinsip, media massa juga melakukan kegiatan jurnalisme dalam batasan-batasan yang disebut dengan etika profesi. Di Indonesia, etika profesi tertuang dalam Kode Etik Jurnalistik (KEJ).

Berdasarkan hasil penelitian yang telah dilakukan, peneliti menemukan adanya usaha Tirto.id dalam menjaga konten-konten yang diproduksi agar tetap sesuai dengan prinsip dan etika jurnalisme ini. Adapun bentuk usaha penerapan prinsip dan etika jurnalisme tersebut, yakni:

1. Penggunaan sumber konten yang dapat dipertanggungjawabka

Tirto.id menggunakan artikel yang diproduksinya sendiri sebagai sumber dari konten infografis di Instagram. Kebijakan ini diambil agar Tirto.id dapat mempertanggungjawabkan secara penuh informasi yang diberikan pada khalayak di media sosial. Meskipun artikel yang ditulis Tirto.id juga berasal dari berbagai sumber, tapi artikel telah melalui tahapan 
editing dan verifikasi sebelum diunggah. Sehingga, penggunaan kembali artikel sebagai sumber data konten media sosial dapat lebih dipertanggungjawabkan.

Penggunaan sumber konten media sosial dari artikel milik Tirto.id sendiri ini, sesuai dengan pasal 2 poin d Kode Etik Jurnalistik: "menghasilkan berita yang faktual dan jelas sumbernya". Tirto.id menunjukkan adanya upaya untuk menerapkan prinsip dan etika jurnalistik ini dengan turut mencantumkan sumber data pada konten infografisnya di Instagram sehingga dapat dipertanggungjawabkan.

2. Mempertimbangkan news value dalam pemilihan konten

Dalam pemilihan artikel yang akan dikurasi, Tirto.id memilih berdasarkan pertimbangan nilai menarik, populer, dan penting. Pertimbangan unsur yang akan ditekankan dan unsur yang akan dikecualikan atau tidak dimasukkan dari sebuah artikel Tirto.id ini dikenal dengan konsep nilai berita atau news value (Wahl-Jorgensen \& Hanitzsch, 2009).

Dalam produksi konten jurnalistik, nilai berita adalah batasan-batasan yang ditetapkan untuk menetapkan sebuah informasi atau peristiwa dapat dikatakan sebagai berita dan layak untuk disebarkan pada khalayak. Nilai berita menjadikan konten media sosial milik media massa berbeda dengan konten media lainnya. Media massa memiliki kewajiban untuk memastikan informasi yang disajikan memang layak disebarkan pada khalayak termasuk dalam konten media sosialnya.

3. Menggunakan berbagai kreatifitas untuk menyajikan konten yang menarik

Konten infografis di InstagramTirto.id memiliki karakter yang berbeda dengan konten infografis di media sosial milik media massa lainnya. Ada tiga karakter unik yang digunakan oleh Tirto.id yakni penggunaan guyonan, maskot "Pak Tirto", dan gambar atau ilustrasi surealis. Ketiga karakter ini adalah kreatifitas yang diterapkan Tirto.id untuk menjadikan konten infografis menarik perhatian khalayak.

"Membuat hal yang penting menjadi menarik dan relevan" adalah elemen ketujuh yang dijelaskan oleh Bill Kovach dan Tom Rosenstiel sebagai elemen jurnalistik. Media tidak hanya bertanggung jawab menyediakan informasi tapi juga menyediakannya dengan cara yang akan membuat khalayak tertarik. Tantangan penting bagi media massa adalah memilih apa yang akan membuat perhatian khalayak terus bertahan (Kovach \& Rosenstiel, 2003).

4. Penerapan etika jurnalistik pada pembuatan desain dan penulisan caption

Tirto.id menerapkan beberapa kebijakan dalam pembuatan desain infografis untuk Instagram. Beberapa di antaranya, pertama, tidak menampilkan gambar mengerikan. Kedua, tidak menampilkan alat-alat atau menjelaskan secara detail proses tindak kriminal seperti pembunuhan, pemerkosaan, bunuh diri. Ketiga, tidak mencemarkan SARA dan nama baik seseorang.

Kebijakan yang ditetapkan Tirto.id ini, sejalan dengan Kode Etik Jurnalistik pada pasal 4 dan pasal 8. Kode Etik Jurnalistik pasal 4 berbunyi: "Wartawan Indonesia tidak membuat berita bohong, fitnah, sadis, dan cabul". Sementara dalam pasal 8 disebutkan bahwa: "Wartawan Indonesia tidak menulis atau menyiarkan berita berdasarkan prasangka atau diskriminasi terhadap seseorang atas dasar perbedaan suku, ras, warna kulit, agama, jenis kelamin, dan bahasa serta tidak merendahkan martabat orang lemah, miskin, sakit, cacat jiwa atau cacat jasmani".

Dalam dunia penyiaran juga dikenal aturan etika penyiaran yang disebut Standar Program Siaran (SPS). Pada pasal 23 juga dijelaskan hal yang sama terkait larangan menampilkan secara detail peristiwa kekerasan, hal mengerikan atau sadisme. Meski dikhususkan sebagai pedoman penyiaran, aturan ini menjadi etika umum bagi seluruh media massa yang menjalankan praktik jurnalisme.

Termasuk pula dalam tahapan pembuatan caption, admin diberikan kebebasan menggunakan kata populer dan tidak baku. Akan tetapi, ada batasan-batasan yang juga 
diterapkan untuk menjaga setiap tulisan caption sesuai dengan prinsip dan etika jurnalistik. Seperti; tidak serampangan, sesuai dengan konteks, dan menggunakan bahasa yang sopan. Admin dituntut untuk membuat caption yang komprehensif dan proporsional, sesuai dengan elemen kesembilan "Jurnalis harus mampu membuat berita komprehensif dan proporsional".

Penerapan strategi cross-media dalam distribusi dan pengembangan konten di Tirto. id menjadi cermin praktik agenda setting dalam proses produksi konten. Agenda setting merupakan tindakan untuk membuat apa yang dianggap penting oleh media, akan dianggap penting pula oleh masyarakat Agenda setting menekankan adanya hubungan positif antara penilaian yang diberikan media pada suatu persoalan, dengan perhatian yang diberikan khalayak pada persoalan tersebut (Nurhadi, 2017, p. 59).

Dalam memproduksi konten infografis, Tirto.id memilih tulisan artikel berdasarkan nilai penting, populer, dan menarik. Ini dapat dilihat dari efek langsung agenda setting yang terjadi di akun Instagramtirtoid. Isu yang dianggap penting oleh khalayak dapat dilihat pada jumlah tanggapan di kolom komentar. Infografis yang memeroleh banyak tanggapan menunjukkan pentingnya isu tersebut bagi khalayak.

Sementara itu dampak yang ditimbulkan dari penggunaan infografis yakni; pertama, bertambahnya kebutuhan Sumber Daya Manusia (SDM) tim produksi. Divisi Media Sosial Tirto.id terdiri dari dua anggota tim di awal tahun 2016. Pada pertengahan tahun 2016, Tirto. id memutuskan untuk menggunakan Instagram sebagai salah satu platform untuk menerapkan strategi cross-media. Setelah kebijakan ini dijalankan, anggota tim terus ditambah. Di tahun 2016, Tirto.id merekrut dua anggota tim dan di tahun 2017 direkrut kembali sebanyak tiga anggota baru. Pada April 2018 lalu, Tirto.id menyebarkan unggahan terkait lowongan sebagai desainer untuk tim media sosialnya, yang menandakan Divisi Media Sosial Tirto.id kembali menambah SDM-nya. Pertambahan SDM yang dilakukan ini adalah salah satu dampak dari diterapkannya strategi cross-media. Strategi cross-media menuntut media massa untuk mampu mengelola beberapa media sosial sekaligus, serta mengembangkan konten dalam bentuk yang berbeda-beda di setiap platform. Dampaknya Tirto.id membutuhkan SDM yang lebih proporsional agar produksi konten berjalan dengan efektif.

Dampak kedua dan ketiga dapat dikatakan sebagai dampak positif bagi Tirto.id. Pertama, strategi cross-media membentuk komunitas mobile brand dalam brand media. Dalam wawancara yang dilakukan peneliti dengan manajer media sosial Tirto.id, Chafifa R. Chazali, Fifa mengakui banyaknya khalayak termasuk klien dari perusahaan besar yang mengenal Tirto.id dari akun Instagram. Inilah yang disebut dengan pembentukan mobile brand dalam brand media. Tirto.id sebagai media daring memperkenalkan brand medianya sebagai media berbasis jurnalisme presisi dengan karakter tulisan panjang atau long form. Penggunaan strategi cross-media, dimana Tirto.id memperluas jangkauan di Instagram dengan konten infografisnya, membentuk sebuah brand baru bagi Tirto.id. Tirto.id kemudian dikenal dengan brand infografisnya di media sosial. Ini berarti penggunaan strategi cross-media membentuk sebuah mobile brand bagi Tirto.id dalam arti Tirto.id dapat memperkenalkan brand medianya kepada khalayak dengan lebih cepat melalui konten-konten cross-media di media sosial. Meski sebagai media baru, Tirto.id mampu membuktikan diri sebagai brand media yang berbeda dan menarik. Kedua, strategi cross-media menawarkan bentuk baru cross-promotion pada klien iklan yang mungkin menarik perhatian pada format iklan baru. Sejak infografis digunakan sebagai bentuk konten utama di Instagram, Tirto.id mengakui klien iklan mulai bermunculan. Ini sesuai dengan hasil observasi peneliti pada akun Instagramtirtoid. Sebelumnya, tidak ada iklan yang diunggah sama sekali di Instagram. Akan tetapi, setelah diberlakukannya kebijakan penggunaan infografis, berbagai iklan mulai muncul dengan bentuk yang sama yakni 
DOI: $10.24198 /$ jkj.v3i2.22276

infografis. Dengan demikian Tirto.id secara tidak sadar telah menawarkan bentuk baru beriklan di medianya yang membuat klien tertarik. Penawaran beriklan dalam bentuk infografis dan disebarkan di berbagai media sosial Tirto.id, merupakan suatu bentuk cross-promoting yang dilakukan oleh Tirto.id sebagai dampak dari digunakannya strategi cross-media.

\section{SIMPULAN}

Tirto.id menggunakan Instagram pada tahun 2016 dengan menyajikan konten foto dan video jurnalistik. Di tahun 2017, Tirto.id mengubah bentuk konten menjadi infografis yang digunakan hingga kini. Kebijakan Tirto.id memilih infografis sebagai bentuk utama konten pada akun Instagram ini dilatarbelakangi atas empat pertimbangan; segmentasi khalayak, sifat dan karakter platform, kemudahan produksi, dan karakter perusahaan. Peneliti menilai empat pertimbangan yang digunakan oleh Tirto.id ini sesuai dengan prinsip utama strategi crossmedia yang menekankan pada kesesuaian pilihan media dengan konten yang disajikan. Tirto.id mampu memahami karakter khalayak dan karakter Instagram dan mengelaborasikan keduanya.

Proses produksi konten infografis pada akun Instagramtirtoid terdiri dari enam tahapan; rapat perencanaan, pembuatan brief, visualisasi brief, editor approving, penjadwalan dan pengunggahan, serta laporan dan evaluasi. Tirto.id juga menerapkan prinsip dan etika jurnalistik sebagai landasan dalam setiap proses produksi kontennya. Di samping itu, Tirto.id membangun karakter khas pada konten infografisnya seperti penggunakan guyonan, maskot "Pak Tirto", dan gambar surealis. Penerapan prinsip dan etika jurnalistik serta karakter khas ini menjadi faktor berkualitas dan menariknya konten infografis Tirto.id di Instagram yang diukur melalui engagement dari khalayak.

Penerapan strategi cross-media dalam distribusi dan pengembangan konten infografis di akun Instagramtirtoid menggunakan prinsip reuse, repackaging, dan recreate. Konten artikel yang telah ada digunakan kembali (reuse) di akun Instagram. Konten kemudian dikemas ulang (repackaging) dalam bentuk infografis. Konten infografis dibentuk ulang (recreate) dan dikembangkan dengan memberikan karakter khas. Cara ini membuat distribusi dan pengembangan konten yang dilakukan Tirto.id menjadi lebih efisien. Di sisi lain, penerapan strategi ini berimplikasi pada praktik agenda setting serta berdampak pada pertambahan kebutuhan Sumber Daya Manusia (SDM) tim produksi, penguatan brand perusahaan, dan peluang baru dalam pemasaran Tirto.id.

\section{DAFTAR PUSTAKA}

APJII. (2016). Infografis Penetrasi dan Perilaku Pengguna Internet Indonesia Survey 2016. Retrieved from https://apjii.or.id/downfile/file/surveipenetrasiinternet2016.pdf

Arigia, M. B. A., Damayanti, T., \& Sani, A. (2016). Infografis Sebagai Media Dalam Meningkatkan Pemahaman Dan Keterlibatan Publik Bank Indonesia. Jurnal Komunikasi, 8(2), 120-133. https://doi.org/10.24912/jk.v8i2.63

Bungin, B. (2008). Konstruksi Sosial Media Massa: kekuatan pengaruh media massa, iklan televisi dan keputusan konsumen serta kritik terhadap Peter L. Berger \& Thomas Luckmann (1st Editio). Jakarta: Kencana Prenada Media Group.

Creswell, J. W. (2013). Research Design: Qualitative, Quantitative, and Mixed Methods Approaches. In Research design Qualitative quantitative and mixed methods approaches. https://doi.org/10.1007/s13398-014-0173-7.2

Feldmann, V. (2005). Leveraging Mobile Media: Cross-Media Strategy and Innovation Policy for Mobile Media Communication. In Journal of Media Business Studies (Vol. 2). https:// doi.org/10.1080/16522354.2005.11073434 
Volume 03 Nomor 02 Tahun 2020

DOI: $10.24198 /$ jkj.v3i2.22276

Insani, C. N., Hidayat, D. R., \& Zulfan, I. (2019). Pemanfaatan Insta Story Dalam Aktivitas Jurnalistik Oleh Majalah Gadis. Jurnal Kajian Jurnalisme, 3(1), 39. https://doi. org/10.24198/jkj.v3i1.22453

Kovach, B., \& Rosenstiel, T. (2003). Elemen-elemen Jurnalisme: Apa yang Seharusnya Diketahui Wartawan dan yang Diharapkan Publik. Jakarta: PANTAU.

Landsverk, K. H. (2014). The Instagram Handbook (2014 Editi). London, United Kingdom: PrimeHead Limited.

Moleong, L. J. (2017). Metodologi Penelitian Kualitatif (Edisi Revisi). In PT. Remaja Rosda Karya (Revision). https://doi.org/10.1016/j.carbpol.2013.02.055

Nasrullah, R. (2016). Media Sosial : Perspektif Komunikasi, Budaya dan Sosioteknologi. Bandung: Simbiosa Rekatama Media.

Nurhadi, Z. F. (2017). Teori Komunikasi Kontemporer (1st Editio). Depok: Penerbit Kencana.

Smiciklas, M. (2012). The Power of Infographics: Using pictures to communicate and connect your audiences. 800 East 96th Street, Indianapolis, Indiana 46240 USA: Que Publishing.

Socha, B., \& Schmid, B. E. (2014). What is New Media? Retrieved February 28, 2018, from new media institute website: https://www.cteonline.org/cabinet/file/22c5f33a-c40c4bc5-a788-01545f5675f5/Preview-of-“WHAT-IS-NEW-MEDIA_”.pdf

Tassel, J. Van, \& Poe-Howfield, L. (2010). Managing Electronic Media: Making, Marketing, and Moving Digital Content. In Focal Press (1st Editio). https://doi.org/10.1017/ CBO9781107415324.004

Wahl-Jorgensen, K., \& Hanitzsch, T. (2009). The Handbook of Journalism Studies (1st Editio). New York: Routledge.

We Are Social. (2016). Digital 2016: Indonesia.

Wicandra, O. B. (2006). Peran Infografis pada Media Massa Cetak. Jurnal Desain Komunikasi Visual Nirmana, 8(1), 44-49. https://doi.org/https://doi.org/10.9744/nirmana.8.1.

Wood, J. T. (2009). Communication in Our Lives (Fifth Edit). Retrieved from http://staffnew. uny.ac.id/upload/132310007/pendidikan/ebook-julia-t-wood-communication-ourlives-2008.pdf

Yin, R. K. (2015). Case Study Research: Design and Methods (5th Editio). London: Sage Publications Ltd. 